\title{
Clinical and epidemiological features of measles in children hospitalized during two outbreaks (2005-2006 and 2017-2018) in Ukraine
}

\author{
V. V. Yevtushenko*A,B, , S. O. Kramarov ${ }^{\mathrm{E}, \mathrm{F}}$, V. O. Shadrin ${ }^{\mathrm{E}}$, A. I. Markov ${ }^{\mathrm{B}}$, T. M. Kaminska ${ }^{\mathrm{C}}$, \\ Ye. O. Hrechukha ${ }^{\mathrm{E}}$
}

Bogomolets National Medical University, Kyiv, Ukraine

A - research concept and design; B - collection and/or assembly of data; C - data analysis and interpretation; D - writing the article; $\mathrm{E}$ - critical revision of the article; $\mathrm{F}$ - final approval of the article

Key words: measles, children, epidemiologic studies.

\section{Zaporozhye} medical journal 2019; 21 (6), 808-814

DOI:

10.14739/2310-1210

2019.6.186607

*E-mail:

evv1972@gmail.com
Aim. The purpose of this study was to find out the clinical and epidemiological features of measles in children during the outbreak of 2017-2018.

Materials and methods. A retrospective study of 230 case histories of children suffering from measles hospitalized in the Kyiv Children's Clinical Hospital was conducted during two epidemic outbreaks in 2005-2006 and 2017-2018.

Results. In 2017-2018, the majority of hospitalized children with measles (62.9\%) were school age children. Compared to 2006 , the mean age of patients has increased significantly, the proportion of children in the first year of life has significantly decreased and the percentage of children of primary school age (6 to 11 years old) has increased. Compared to 2005-2006, an increase in the duration of fever (from 6.60 to 7.26), shortening of prodromal period (from 3.68 to 2.96) and prolongation of rash period (from 4.97 to 5.88) are characteristic of the course of measles in 2017-2018. Leukopenia was observed in almost every fifth patient. In $14.3 \%$ of patients in $2017-2018$, the course of the disease was complicated (the vast majority was associated with respiratory tract organs). Compared to 2005-2006, the structure of patients with measles in 2017-2018 had the proportion of vaccinated patients decreased and, respectively, the percentage of unvaccinated individuals increased: the proportion of unvaccinated patients was $72.1 \%$; unknown vaccination status $-2.9 \%$. Approximately $10.0 \%$ of children had only one administration of a measles vaccine.

Conclusions. During the current outbreak, school age children and adolescents prevail in the age structure of ill children hospitalized with measles. Compared to 2005-2006, an increase in the duration of fever, shortening of prodromal period and prolongation of rash period are characteristic of the course of measles in 2017-2018. Changes in the clinical and epidemiological features of the disease may be associated with changes in the spectrum of circulating strains of measles virus.

Кюючові слова: кір, Аіти, епідеміологічн АосліАження.

Запорізький медичний

журнал. - 2019. -

T. 21, № 6(117). -

C. 808-814

\section{Кмінічні та епідеміологічні особливості кору в госпіталізованих дітей під час Авох спалахів (2005-2006 і 2017-2018 років) в Україні}

\section{В. В. Євтушенко, С. О. Крамарьов, В. О. Шадрін, А. І. Марков, Т. М. Камінська, Є. О. Гречуха}

Мета роботи - дослідження виявлення клінічних та епідеміологічних особливостей кору в дітей під час спалаху 2017-2018 років.

Матеріали та методи. Виконали ретроспективне дослідження 230 історій клінічних випадків дітей, які хворі на кір і госпіталізовані в Київську міську дитячу клінічну інфеекційну лікарню під час двох спалахів епідемії кору у 2005-2006 та 2017-2018 роках.

Результати. У 2017-2018 р. більшість госпіталізованих дітей із кором (62,9 \%) - шкільного віку. Порівняно з 2006 р. середній вік пацієнтів суттєво збільшився, частка дітей на першому році життя істотно зменшилася, а частка дітей молодшого шкільного віку (від 6 до 11 років) значущо збільшилася. Порівняно з 2005-2006 р. під час спалаху 2017-2018 р. характерне збільшення тривалості лихоманки (з 6,60 до 7,26 дня), скорочення продромального періоду ( 3 3,68 до 2,96 дня), подовження періоду висипання (з 4,97 до 5,88 дня). Лейкопенію спостерігали майже в кожного п'ятого пацієнта. У 14,3 \% всіх пацієнтів у 2017-2018 р. захворювання мало перебіг з ускладненнями (здебільшого з боку органів дихання). Порівняно з 2005-2006 p. у структурі хворих на кір у 2017-2018 р. частка вакцинованих хворих зменшилася і, відповідно, відсоток невакцинованих осіб збільшився: частка невакцинованих пацієнтів становила 72,1 \%; частка дітей із невідомим вакцинальним статусом 2,9%. Майже 10,0 \% дітей мали тільки одне введення вакцини проти кору.

Висновки. Під час останнього спалаху у віковій структурі дітей із кором, яких госпіталізували, переважають діти та підлітки шкільного віку. Порівняно зі спалахом 2005-2006 р. у 2017-2018 р. встановили збільшення тривалості лихоманки, скорочення продромального періоду та продовження висипання. Зміни клінічних, епідеміологічних особливостей захворювання можуть бути пов'язані зі зміною спектра штамів вірусу кору, що циркулюють.

\section{Клинические и эпидемиологические особенности кори у госпитализированных детей во время Авух вспышек (2005-2006 и 2017-2018 гг.) в Украине}

\author{
В. В. Евтушенко, С. А. Крамарев, В. О. Шадрин, А. И. Марков, Т. Н. Каминская, Е. О. Гречуха
}

Цель работы -установление клинических и эпидемиологических особенностей кори у детей во время вспышки 2017-2018 годов. 
Материалы и методы. Выполнено ретроспективное исследование 230 историй клинических случаев детей, страдающих корью и госпитализированных в Киевскую городскую детскую клиническую инфекционную больницу во время двух вспышек эпидемии кори в 2005-2006 и 2017-2018 гг.

Результаты. В 2017-2018 г. большинство госпитализированных детей с корью (62,9 \%) - школьного возраста. По сравнению с 2006 г. средний возраст пациентов значительно увеличился, доля детей на первом году жизни значительно уменьшилась, а доля детей младшего школьного возраста (от 6 до 11 лет) значительно увеличилась. По сравнению с 2005-2006 г. во время вспышки 2017-2018 г. характерно увеличение продолжительности лихорадки (с 6,60 до 7,26 дня), сокращение продромального периода (с 3,68 до 2,96 дня) и удлинение периода высыпания (с 4,97 до 5,88 дня). Лейкопения отмечена почти у каждого пятого пациента. У 14,3 \% пациентов в 2017-2018 г. заболевания протекало с осложнением (большинство - со стороны органов дыхания). По сравнению с 2005-2006 г. в структуре заболевших корью в 2017-2018 г. доля вакцинированных больных уменьшилась и, соответственно, процент вакцинированных лиц увеличился: доля невакцинированных пациентов составила 72,1 \%; доля детей с неизвестным вакцинальным статусом - 2,9%. Примерно 10,0 \% детей имели только одно введение вакцины против кори.

Выводы. Во время нынешней вспышки в возрастной структуре госпитализированных детей с корью преобладают дети и подростки школьного возраста. По сравнению со вспышкой 2005-2006 г. в 2017-2018 г. характерно увеличение продолжительности лихорадки, сокращение продромального периода и удлинение высыпания. Изменения клинических и эпидемиологических особенностей заболевания могут быть связаны с изменением спектра циркулирующих штаммов вируса кори.

Measles is a highly contagious disease of viral nature. Before the use of the measles vaccine in 1963 in the United States and the introduction of a large-scale vaccination, epidemic outbreaks were observed every 2-3 years, and the number of deaths from this infection reached approximately 2.6 million people annually. However, even despite the availability of a safe and effective vaccine, this disease remains one of the main causes of death among children throughout the world. In 2016, approximately 89.780 people died as a result of the measles, mostly children under 5 years old [1]. In Ukraine, several epidemic outbreaks of measles infection occurred over the past few years (Fig. 1).

The most powerful outbreak in the last two decades in Ukraine was recorded in 2006, during which 42.724 cases of this disease were registered (Source, date and content of request Consulted experts WHO Regional Office for Europe-Alert and Response Operations Main conclusions and recommendations). According to the Center for Public Health of the Ministry of Health of Ukraine (PHC), more than 41.000 children and adults were affected by measles in the European Region in 6 months of 2018. In seven countries of the European Region (Greece, Georgia, Italy, Russian Federation, Serbia, Ukraine and France), more than 1000 cases of measles in children and adults in each of these countries were recorded. In Ukraine, on the 41 st week since the beginning of the year, measles was diagnosed in 33.165 people, including 13.184 adults and 19.981 children (PHC).

The outbreak of measles of 2006 in Ukraine was caused mainly by the measles virus genotype D6 [2]. However, during the last outbreak, which is still ongoing, the circulation of other variants of measles virus including genotypes B3, D8 and D9 is observed on the territory of Ukraine.

We suggested that the emergence of new varieties of measles virus could lead to certain changes in the clinical picture of the disease.

\section{Aim}

The purpose of this study was to find out the clinical and epidemiological features of measles in children during the outbreak of 2017-2018.

\section{Material and methods}

A retrospective study of 230 case histories of children suffering from measles hospitalized in the Kyiv Children's Clinical Hospital (KCCH) was conducted during two epidemic outbreaks in 2005-2006 and 2017-2018.

Mean values (M) and standard deviations (SD) were calculated for data presentation. The difference between the quantitative indicators was determined using the oneway or multivariate ANOVA. In the case of non-compliance with normal distribution and / or insignificant number of variants, the Mann-Whitney test was used; categorical values were analyzed using the odd ratio $(\mathrm{OR})$ and the Xisquare test $\left(\mathrm{Xi}^{2}\right)$. Statistically significant difference was considered at $\mathrm{P}<0.05$.

\section{Results}

The diagnosis was based on clinical and epidemiological data (contact with measles patients, a typical clinical aspect), confirmed by PCR studies and the determination of specific IgM antibodies.

Patients were divided into two groups: one group included 90 children hospitalized during 2005-2006; and 140 children during 2017-2018. Age and gender characteristics of patients are presented in Table 1.

In 2017-2018, the majority of hospitalized children with measles $(62.9 \%)$ were school age children. Compared to 2006, the mean age of patients has increased significantly, the proportion of children in the first year of life has significantly decreased and the percentage of children of primary school age (6 to 11 years old) has increased $(P<0.0001)$. The gender structure did not change significantly $(P>0.05)$.

In 2017-2018, the proportion of patients unvaccinated against measles was $72.1 \%$ and vaccination status was unknown in 4 (2.9\%) (Table 2). In the group of children of 1 to 2 years old, unvaccinated patients accounted for $75.0 \%$, 2 to 5 years old $-72.4 \%, 6$ to 11 years old $-83.3 \%$, over 12 years old $-55.9 \%$. Among patients with measles, 21 $(15.0 \%)$ were vaccinated in full, while another 14 (10.0\%) children over 6 years old had only one administration of a measles vaccine. The total number of patients who received at least one vaccine was $35(25.0 \%)$. The largest proportion of children suffering from measles who had a history of
Кнючевые слова: корь, Аети, эпидемиологические исследования.

Запорожский медицинский журнал. - 2019. T. 21, № 6(117). C. $808-814$ 


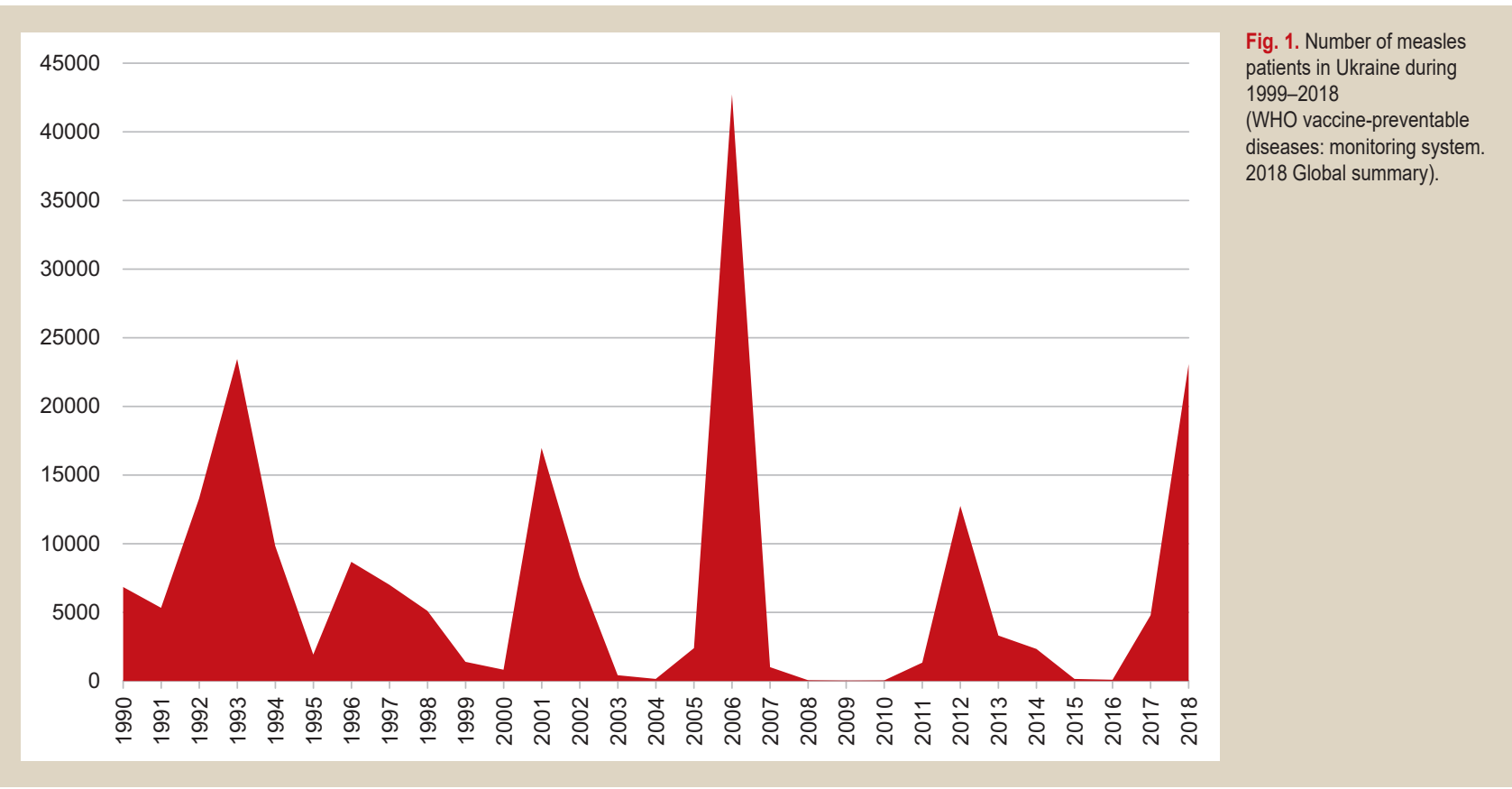

Table 1. Age and gender features of measles patients

\begin{tabular}{|l|l|l|l|}
\hline Feature & $\mathbf{2 0 0 6}(\mathrm{n}=\mathbf{9 0})$ & $\mathbf{2 0 1 8}(\mathrm{n}=\mathbf{1 4 0})$ & $\mathbf{P}$ \\
\hline Age, years $(\mathrm{M} \pm \mathrm{SD})$ & $6.12 \pm 6.61$ & $7.70 \pm 5.33$ & 0.047 \\
\hline 0-1 years old $(\mathrm{n} / \%)$ & $24 / 26.7 \%$ & $12 / 8.6 \%$ & 0.0002 \\
\hline 1-2 years old $(\mathrm{n} / \%)$ & $15 / 16.7 \%$ & $11 / 7.9 \%$ & ID \\
\hline 2-5 years old $(\mathrm{n} / \%)$ & $16 / 17.8 \%$ & $29 / 20.7 \%$ & ID \\
\hline 6-11 years old $(\mathrm{n} / \%)$ & $8 / 8.9 \%$ & $54 / 38.6 \%$ & $<0.0001$ \\
$>12$ years old $(\mathrm{n} / \%)$ & $27 / 30.0 \%$ & $34 / 24.3 \%$ & ID \\
\hline Boys $(\mathrm{n} / \%)$ & $42 / 46.7 \%$ & $77 / 55.0 \%$ & ID \\
\hline Girls $(\mathrm{n} / \%)$ & $48 / 53.3 \%$ & $63 / 45.0 \%$ & ID \\
\hline
\end{tabular}

ID: insignificant difference $(P>0.05)$.

Table 2. Clinical and epidemiological features of patients

\begin{tabular}{|l|l|l|l|}
\hline Feature & $\mathbf{2 0 0 6}(\mathrm{n}=\mathbf{9 0})$ & $\mathbf{2 0 1 8}(\mathrm{n}=\mathbf{1 4 0})$ & $\mathbf{P}$ \\
\hline Vaccination MMR (n/\%) & $32 / 35.6 \%$ & $35 / 25.0 \%$ & $\mathrm{ID}$ \\
\hline Inpatient treatment (days) & $5.98 \pm 2.34$ & $5.98 \pm 2.82$ & $\mathrm{ID}$ \\
\hline Duration of fever (days) & $6.60 \pm 2.33$ & $7.26 \pm 1.88$ & 0.020 \\
\hline Duration of prodromal stage (days) & $3.68 \pm 1.50$ & $2.96 \pm 1.46$ & 0.0002 \\
\hline Duration of rush (days) & $4.97 \pm 1.12$ & $5.88 \pm 1.77$ & 0.0001 \\
\hline Leukopenia (n/\%) & $20 / 22.2 \%$ & $32 / 22.9 \%$ & ID \\
\hline Complications (n/\%) & $20 / 22.2 \%$ & $18 / 12.9 \%$ & ID \\
\hline Concomitant pathology (n/\%) & $13 / 14.4 \%$ & $19 / 13.6 \%$ & ID \\
\hline
\end{tabular}

Vaccination MMR: documented administration of at least one vaccine dose; Complications: number and percent of patients with complicated course; Concomitant pathology: number of patients with concomitant pathology; ID: insignificant difference ( $P>0.05)$.

vaccination was observed in the group of children over 12 years old $-44.1 \%$, the smallest - in the group of children of 6-11 years old $-16.7 \%$. Compared to 2005-2006, the structure of patients with measles in 2017-2018 had the proportion of vaccinated patients decreased and, respectively, the percentage of unvaccinated individuals increased.

The duration of inpatient treatment in 2017-2018 varied from 1 to 19 days $(5.96 \pm 2.85, M \pm S D)$. Compared to 2005-2006, the mean duration of inpatient treatment did not change significantly (Table 2). The duration of inpatient treatment did not significantly depend on the age of patients: it was $5.57 \pm 2.10$ days (2 to 12 days) in children in the first year of life, $5.63 \pm 3.97$ days ( 1 to 19 days) in 1-2-year-old children, $6.07 \pm 1.96$ days (2 to 11 days) in 2-5-year-old children, $6.02 \pm 2.39$ days ( 1 to 16 days) in 6-11-year-old children, $6.26 \pm 2.88$ days ( 1 to 16 days) in children over 12 years old. Among children vaccinated against measles (at least 1 dose of the vaccine), the duration of stay in the hospital was $6.03 \pm 2.44$ days ( 1 to 14 days), among non-vaccinated $-5.94 \pm 2.75$ days ( 1 to 19 days) $(P>0.05)$. The duration of stay in a hospital was significantly longer in patients with the complicated course of measles $-8.10 \pm 2.93$ days compared to patients without complications $-5.53 \pm 2.35$ days $(P=0.00001)$.

Classic triad - conjunctivitis, cough and runny nose was present in $79.1 \%$ of patient. Conjunctivitis was observed in $85.7 \%$ of patients, cough - in $96.1 \%$, runny nose - in $87.8 \%$. Another known symptom of measles infection, the Koplik's spots, was documented in $90.0 \%$ of patients.

Fever was observed in all patients. There was no significant difference in the level of fever between different age groups $(P>0.05)$. In children vaccinated with at least one dose of measles vaccine, the body temperature was $39.3 \pm 0.6^{\circ} \mathrm{C}\left(37.5\right.$ to $\left.40.0^{\circ} \mathrm{C}\right)$, the duration of the fever was $6.6 \pm 1.74$ days ( 1 to 10 days). In unvaccinated patients, respectively, the body temperature was $39.3 \pm 0.55^{\circ} \mathrm{C}(38.0$ to $40.5^{\circ} \mathrm{C}$ ), duration was $7.5 \pm 1.92$ days ( 4 to 13 days) significantly longer $(P=0.018)$. Compared to 2005-2006, the mean duration of fever significantly increased in children undergoing treatment in 2017-2018 (Table 2).

The average duration of the prodromal period in patients with measles in 2017-2018 was significantly shorter compared to 2005-2006 data (Table 2). We observed a decrease in the duration of this period in all age groups. Moreover, we did not find a significant relationship between the duration of the prodromal period and age: among all patients (2005-2006 and 2017-2018), the mean duration 


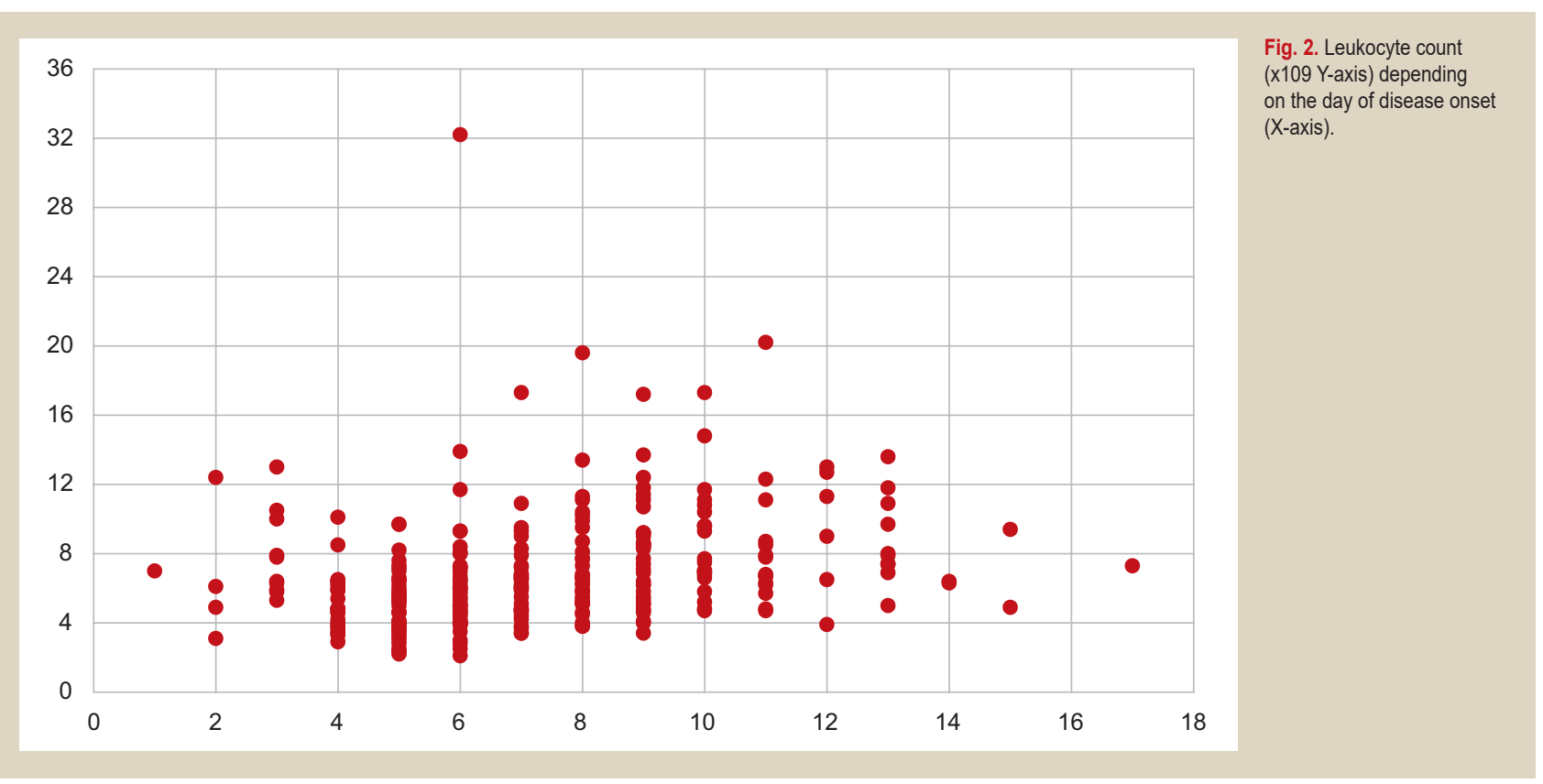

in children in the first year of life was $3.1 \pm 1.55$ days ( 1 to 6 days), $1-2$ years old: $3.4 \pm 1.62$ days ( 1 to 7 days), $2-5$ years old: $3.3 \pm 1.30$ days ( 1 to 6 days), $6-12$ years old: $3.1 \pm 1.56(P>0.05)$. Among unvaccinated individuals, the prodromal period lasted $3.2 \pm 1.47$ days ( 1 to 8 days) and was significantly longer than that in patients vaccinated with minimum one single administration of measles vaccine: $2.4 \pm 1.31$ days ( 1 to 6 days) $(P=0.004)$.

Rush was present in all patients. In all cases, the rush was maculopapular with a tendency to fuse. In $97.0 \%$ of patients, there was a progression of rash with characteristic distribution from the head to the distal parts of limbs. In all patients, the spread of rash lasted 2-3 days. The rash was present on the skin for an average of 5.55 days ( 3 to 12 days). In comparison with 2005-2006, the duration of rash was significantly longer in 2017-2018. The duration of rash did not significantly depend on the vaccination status and was $5.63 \pm 1.73$ days ( 3 to 12 days) in unvaccinated patients and $5.30 \pm 1.30$ days ( 3 to 10 days) in vaccinated patients (at least one vaccine) $(P>0.05)$. At the same time, according to the results of our observation, the duration of rash depended on the child's age. In children in the first year of life, the duration of rash was $4.96 \pm 1.29$ days, in 1-2 year-old patients: $6.09 \pm 2.11$ days, in $2-5$ year-old patients: $5.60 \pm 1.29$ days, in $6-11$ year-old patients: $6.02 \pm 1.78$ days, in patients over 12 years old: $5.13 \pm 1.44$ days $(P=0.0058)$.

The count of peripheral blood leukocytes in patients in 2017-2018 ranged from 2.1 to $32.2 \mathrm{G} / \mathrm{L}$. In $96.3 \%$ of patients in the first study, there was a shift of neutrophils towards their young forms. The percentage of stab neutrophils in the first study on the first day of hospitalization ranged from 1 to $37 \%$ (15.2 $\pm 7.42 \%)$. Leukocyte count depending on the day of examination is shown in Fig. 2. A decrease in the number of leukocytes was observed predominantly during days 4-6 of the disease. An elevated leukocytes count (more than $9 \mathrm{G} / \mathrm{L}$ ) was typical in the interval from days 6 to 13 from the onset of the disease.

Leukopenia, one of the most common laboratory symptoms of measles, was observed in almost every fifth patient in both 2005-2006 and 2017-2018. Overall, among patients examined in 2017-2018, leukopenia (leukocyte count $<4 \mathrm{G} / \mathrm{L}$ ) was observed in 38 patients. Leukopenia was recorded in patients from 2 to 12 days from the onset of the disease ( $5.6 \pm 1.72$ days). Leukopenia was recorded in patients of all age groups from 11 months to 17 years 11 months old ( $8.8 \pm 5.01$ years). There was no significant difference depending on vaccination status.

In $22.2 \%$ of patients in 2005-2006 and in $14.3 \%$ of patients in 2017-2018, the course of the disease was complicated (Table 2). The incidence among children in the first year of life was $16.7 \%$, in the age group from 1 to 2 years old: $23.1 \%$, in $2-5$-year old patients: $17.8 \%$, in $6-11$-year old patients: $11.3 \%$, in patients over 12 years old: $21.3 \%$ (frequency depending on age was not significant). The incidence of complications was $18.1 \%$ among unvaccinated patients and $15.7 \%$ among vaccinated ones (at least 1 vaccine), $\mathrm{OD}=1.09(0.51-2.34)$. Table 3 presents the spectrum and frequency of individual complications.

Bronchitis was observed in 8 children, of whom 3 patients were of the first year of life, 2 patients of 2 to 5 years old, 2 patients of 6 to 11 years old and 1 patient over 12 years old.

Pneumonia complicated the course of measles in seven patients. In all cases, this was a secondary bacterial complication. The durations of pneumonia were within 4-6 days (median -6 days). In all cases, pneumonia was confirmed radiologically. One patient had pneumonia complicated by pleuritis. Three children had pneumonia accompanied by respiratory insufficiency and the use of supportive oxygen therapy was required. Bacterial complications from ENT organs occurred in 11 patients. Among them, there were six cases of sinusitis and five cases of otitis media. All cases were registered among children over 6 years old. The frequency of respiratory organ complications in 2018 did not differ significantly from the data for 2006.

Gingivostomatitis was observed in six patients of early age (under 2 years old) in 2005-2006. In 2017-2018, such 
Table 3. Features of complications in patients with measles

\begin{tabular}{l|l|l|l|}
\hline Complications & $\begin{array}{l}\text { 2005-2006 } \\
(\mathbf{n = 9 0})\end{array}$ & $\begin{array}{l}\mathbf{2 0 1 7 - 2 0 1 8} \\
(\mathbf{n = 1 4 0 )}\end{array}$ & $\mathbf{P}$ \\
\hline Bronchitis & $5 / 5.56 \%$ & $3 / 2.14 \%$ & ID \\
\hline Hepatitis & 0 & $2 / 1.43 \%$ & ID \\
\hline Retinal dystrophy & $1 / 1.11 \%$ & 0 & ID \\
\hline Diarrhea & $4 / 4.44 \%$ & 0 & 0.023 \\
\hline Respiratory failure & 0 & $3 / 2.14 \%$ & ID \\
\hline Encephalitis & 0 & $2 / 1.43 \%$ & ID \\
\hline Cardiomyopathy & 0 & $1 / 0.71 \%$ & ID \\
\hline Otitis & $1 / 1.11 \%$ & $4 / 2.86 \%$ & ID \\
\hline Pneumonia & $4 / 4.44 \%$ & $4 / 2.86 \%$ & ID \\
\hline Sinusitis & $1 / 1.11 \%$ & $5 / 3.57 \%$ & ID \\
\hline Stomatitis & $6 / 6.67 \%$ & 0 & 0.003 \\
\hline Febrile seizures & $1 / 1.11 \%$ & 0 & ID \\
\hline Total & $22 / 24,44 \%$ & $23 / 15,71 \%$ & ID \\
\hline
\end{tabular}

Hepatitis: increase in ALT > 2N. ID: insignificant difference $(P>0.05)$.

cases were not observed among studied patients. Among patients of 2005-2006, manifestations of gastroenteritis were observed in four cases.

In 2018, we observed two patients with CNS damage. Among them, a girl of 5.5 years old, unvaccinated against measles, whose disease started suddenly with a temperature rise to febrile values, the appearance of catarrhal phenomena. On the 3rd day of the disease, a maculopapular rash appeared on the face that spread throughout the body during the next 24 hours. On the 5th day, the general condition of the child worsened, she became sleepy, refused to eat, could not rise from the bed without help, pain in the legs and back appeared, while the rash on the skin at that time disappeared. On the 6th day of the disease, during the examination, an impairment of consciousness was recorded (score 13 based on the Glasgow Coma Scale, E4V4M5); the physical examination showed positive meningeal symptoms (rigor of the occipital muscles, Kernig's and Brudzinski's signs), symptoms of spinal nerve roots tension (Neri's sign). The child was not accessible for the productive contact. The face was symmetrical. The bulbar group of the cranial nerves was not impaired. Pupils $D=S$, moderately expanded, photoreaction was preserved, conjugate. General muscular hypotonia. Abdominal reflexes were absent. There were no seizures and vomit. Body temperature was 36.4-36.6. Microcirculation was not affected. Breathing was spontaneous, effective, biomechanics was not impaired, with the support of humidified oxygen through a face mask. Heart rate was $58-86 /$ min, blood pressure was 103/41$83 / 48 \mathrm{mmHg}$. Peristalsis was preserved. There was no self-defecation. Diuresis was sufficient at $3 \mathrm{ml} / \mathrm{kg} / \mathrm{hr}$. During the next 3 days, the state of consciousness deteriorated. At day 8 of the disease, a result of measles-specific IgM study was obtained. On the day 9 of the disease, the level of consciousness was 9 based on the Glasgow Coma Scale (E4V1M4), bradycardia increased to $44 / \mathrm{min}$, there was a decrease in blood pressure to $65 / 40 \mathrm{mmHg}$. Cerebrospinal fluid analysis revealed slight lymphocytic pleocytosis, while a MRI study showed scattered focal changes. From the $10^{\text {th }}$ day of the disease, there was a gradual improvement of the child's condition. Restoration of consciousness was observed on day 12. During discharge from the hospital on the $18^{\text {th }}$ day of the disease, the child had minor manifestations persisted in the form of a decrease in muscular strength in the limbs, increased fatigue.

Another child, an 11-year-old girl, was hospitalized to the $\mathrm{KCCH}$ with an impairment of consciousness (score 9 according to the Glasgow Coma Scale, E4V1M4). No impairments of the cranial nerves were observed. Abdominal reflexes were not activated. Muscle tone was lowered. Breathing was spontaneous, effective. Hemodynamics was stable. The disease history showed that the child suffered from measles at the age of 9 months old. 1.5 years ago, the girl suddenly began having her motor function impaired in the form of spontaneous tremor of hands, inclination of her head to the right, episodes of involuntary falls up to 30 times a day. Subsequently, there were periods of deterioration and improvement of her neurological status. Four days before hospitalization in our clinic, the child became sleepier, the intensity of myoclonus and hallucinatory reactions increased. On the day of hospitalization, the child had consciousness impaired to the level of a sopor (score 9 according to the Glasgow Coma Scale, E4V1M4), and lymphocytic pleocytosis was detected in the cerebrospinal fluid. MRI of the brain showed signs of periventricular leukoaraiosis. The results of the cerebrospinal fluid test for the markers of toxoplasmosis, CMV, EBV, VZV, HSV1/2, HHV 6-7 (PCR) were negative, but a high titer of $\lg G$ antibody to measles virus was detected. The child received empirical antiviral therapy (acyclovir), immunomodulatory therapy (corticosteroids, intravenous immunoglobulin), supportive and symptomatic agents. However, despite the treatment, the condition of the child progressively deteriorated with the gradual development of multiple organ failure. On the day 18 of inpatient treatment, the patient had a cardiac arrest associated with increased cardiac insufficiency and the development of DIC-syndrome, and death of the patient was recorded.

Manifestations of liver damage were observed in two patients in 2017-2018. They showed an increase in transaminases, including an increase in ALT of more than two normal values. There were no clinical manifestations of hepatic dysfunction in these patients. In both cases, a spontaneous normalization of the ALT level was observed, the duration of hypertransferasemia did not exceed 10 days.

Concomitant pathology in patients with measles was found to be practically identical in 2006 and 2018 (Table 2). We took into account both the premorbid condition and the cases of acute diseases that developed during the stay of patients with measles in the hospital and were not associated with the underlying disease by causative relationships. Concomitant pathology was represented by a broad spectrum of chronic and acute diseases, among which allergic dermatitis was most common (5 cases), congenital heart disease ( 3 cases), chicken pox ( 3 cases), deficiency anemia ( 3 cases), ascariasis ( 2 cases), bronchial asthma (2 cases). Among other rare cases, patients with HIV infection, epilepsy, hemophilia, diabetes mellitus, rheumatoid arthritis, and urinary tract infections should be noted. We found that the presence of concomitant pathology was associated with a higher frequency of complications. On the background of concomitant pathology, the incidence of complications was $34.4 \%$, and in children without concomitant pathology $-15.7 \%\left(P=0.006, X^{2}\right.$ test $)$. 


\section{Discussion}

The measles incidence depends on many factors, among which the level of coverage by prophylactic vaccination is the key. After the introduction of planned measles vaccination in Ukraine in 1966-1967 and revaccination in 1986, the incidence rate decreased significantly, the proportion of children in the structure of patients decreased and inter-epidemic intervals increased to 5-6 years. However, after 2008, the coverage rate for measles vaccination in Ukraine declined to less than $95 \%$, reaching a minimum in 2017-2018. In particular, according to WHO, the first dose of measles vaccine in 2017-2018 was received by $42 \%$ of children, while the second dose of the vaccine was received by only $31 \%$ of children [3]. The results of this study indicate that the majority of patients were unvaccinated individuals, and, accordingly, the cause of epidemic surge is a decrease in the coverage by scheduled vaccination.

The hospitalization of children with measles infection and the duration of stay in a hospital is usually conditioned both by clinical and epidemiological indications. We did not see any significant changes in the length of hospital stay between patients in 2005-2006 and 2017-2018. Also, the observation showed that the duration of inpatient treatment did not significantly depend on the age of patients and their vaccination status. The only factor that had a reliable connection with the extension of the time of inpatient treatment was a complicated course of measles. Our results regarding this indicator do not differ significantly from the data of other studies. In particular, 13 years ago in China, Lee K-Y. who analyzed the data of three epidemic outbreaks during 1989-2001 (a total of 520 patients) reported the duration of inpatient treatment ranged from 5.7 to 6.4 days. In another his study, a relationship between clinical features of measles was studied, in particular the duration of inpatient treatment, the age of patients. According to the results, the mean stay in a hospital lasted from 5.1 to 6.0 days and did not depend on the age of children.

The fever has been selected as a clinical criterion for infection, since it can be objectified and generally reflects the duration of the acute period of an infectious disease. The results of our observation demonstrated some regularities of this symptom. In particular, according to our data, the duration of fever in vaccinated patients was significantly shorter than that in unvaccinated ones. In addition, we noted that the duration of the fever in patients with measles in 2018 has increased significantly compared to 2006 . These changes were not related to changes in age structure, complications development and percentage of vaccinated people. In our opinion, this tendency may be due to changes in the etiological pattern, in particular the circulation of nontraditional genotypic variants of the virus for this territory.

Other interesting features of the clinic of measles in 2017-2018, compared to the previous epidemic period, were a relative reduction in the prodromal period and prolonged duration of rash. In particular, a reduction in the duration of the prodromal period was observed in all age groups of patients. This tendency could be even more pronounced, because the proportion of unvaccinated children, who, according to our data, are characterized by a longer prodromal period, has increased in the structure of patients since 2017-2018.
As for the duration of rash, we have established that it depended on the age of patients. According to the results of our observation, it was relatively shorter in children in the first year of life and in patients over 12 years old. Taking into account that the proportion of children of the first year of life in the structure of patients relatively decreased and the number of children from 2 to 11 years increased, it is reasonable to assume that the lengthening of rash duration may be related, in particular, to the change in the age structure of patients.

An important pathogenetic feature of measles is suppression of the immune system. It is associated with the development of secondary complications and the severity of the course of the disease. Although the mechanism of immune suppression has not been fully understood yet, the leading links include the impairment of lymphocyte proliferation, suppression of hemopoiesis, damage of immunological memory and the destruction of the epithelial barrier [4-7]. Leukopenia, the most known manifestation of immune suppression, correlates with the time of appearance and severity of viremia [5]. According to our observation, leukopenia was observed in more than $22 \%$ of patients. More often, the decrease in the number of leukocytes was recorded 4-6 days of the disease.

The immunosuppressive effect of measles virus is directly related to the development of complications. The most important and frequent complications of measles is pneumonia, the frequency of which according to various studies varies from $14 \%$ to $66 \%[8,9]$. Among our patients, pneumonia was also a relatively frequent complication, but its frequency did not exceed $4.5 \%$. This is probably due to broader indications for hospitalization in our clinic, which do not restrict the stay of patients with non-severe forms of the disease in the inpatient facility. In particular, in the city of Kyiv, more than $70 \%$ of measles patients were hospitalized during the epidemic outbreak of 2018.

Impairments of the nervous system are among the most severe complications in measles [10]. Their development is possible due to direct damage by the virus, immune-mediated damage (post-infection encephalitis) as well as in the form of subacute sclerosing panencephalitis [11]. Among our patients, we observed a case of postinfectious meningoencephalitis and subacute sclerosing panencephalitis. The second one is generally more difficult for correct diagnosis due to a very long period between primary disease (measles) and its neurological complication [12].

Common complications of measles are also considered to be liver damage. The manifestations of this complication may vary from subclinical change in laboratory parameters to manifestations of fulminant hepatitis (especially in infants [13]). According to published studies, hepatitis and liver dysfunction are more common in children over 15 years old and in adults. The frequency of this complication can reach as much as $80 \%$ [11-14]. In our observation, manifestations of hepatitis were recorded in two patients. Both belonged to the age group of older children (15 and 17 years old). In both cases, liver changes were limited to an increase in transaminases and were not accompanied by clinical symptoms.

A classic complication of measles is thought to be diarrhea. Previous studies indicate that the frequency of this 
complication in patients with measles varies according to some data but can be very serious [12-15]. We observed the manifestations of gastroenteritis in four patients who belonged to the category of early age children. All these cases were recorded among patients during the epidemic breakout of 2005-2006. No diarrhea was observed among patients in 2017-2018.

\section{Conclusions}

1. During the current outbreak, school age children and adolescents prevail in the age structure of ill children hospitalized with measles.

2. Compared to 2005-2006, an increase in the duration of fever, shortening of prodromal period and prolongation of rash period are characteristic of the course of measles in 2017-2018.

3. Changes in the clinical and epidemiological features of the disease may be associated with changes in the spectrum of circulating strains of measles virus.

Conflicts of interest: authors have no conflict of interest to declare. Конфлікт інтересів: віАсутній.

Надійшла до редакції / Received: 15.03.2019

Після Аоопрацювання / Revised: 08.04.2019

Прийнято Ао Аруку / Accepted: 19.04.2019

Information about authors:

Yevtushenko V. V., MD, PhD, Associate Professor of the Department of Pediatric Infectious Diseases, Bogomolets National Medical University, Kyiv, Ukraine. Kramarov S. O., MD, PhD, DSc, Professor, Head of the Department of Pediatric Infectious Diseases, Bogomolets National Medical University, Kyiv, Ukraine.

Shadrin V. O., MD, PhD, Assistant of the Department of Pediatric Infectious Diseases, Bogomolets National Medical University, Kyiv, Ukraine.

Markov A. I., MD, Postgraduate student of the Department of Pediatric Infectious Diseases, Bogomolets National Medical University, Kyiv, Ukraine.

Kaminska T. M., MD, PhD, DSc, Assistant of the Department of Pediatric Infectious Diseases, Bogomolets National Medical University, Kyiv, Ukraine.

Hrechukha Ye. O., MD, Senior Laboratory Assistant of the Department of Pediatric Infectious Diseases, Bogomolets National Medical University, Kyiv, Ukraine.

\section{Інформація про авторів:}

Євтушенко В. В., канА. меА. наук, Аоцент каф. Аитячих інфекційних хвороб, Національний меАичний університет імені О. О. Богомольця, м. Київ, Україна.

Крамарьов С. О., А-р меА. наук, професор, зав. каф. Аитячих інфекційних хвороб, Національний меАичний університет імені 0. О. Богомольця, м. Київ, Україна.

Шалрін В. О., канА. меА. наук, асистент каф. Аитячих інфекційних хвороб, Національний медичний університет імені О. О. Богомольця, м. Київ, Україна.

Марков А. І., аспірант каф. Аитячих інфекційних хвороб, Національний медичний університет імені О. О. Богомольця, м. Київ, Україна.

Камінська Т. М., А-р меА. наук, асистент каф. Аитячих інфекційних хвороб, Національний медичний університет імені О. О. Богомольця, м. Київ, Україна.

Гречуха Є. О., старший ^аборант каф. Аитячих інфекційних хвороб, Національний меАичний університет

імені О. О. Богомольця, м. Київ, Україна.
Сведения об авторах:

Евтушенко В. В., канА. меА. наук, Аоцент каф. Аетских инфекционных болезней, Национальный медицинский университет имени А. А. Богомольца, г. Киев, Украина. Крамарев С. А., А-р меА. наук, профессор, зав. каф. Аетских инфекционных болезней, Национальный медицинский университет имени А. А. Богомольца, г. Киев, Украина. Шалрин В. О., канА. меА. наук, ассистент каф. Аетских инфекционных болезней, Национальный медицинский университет имени А. А. Богомольца, г. Киев, Украина. Марков А. И., аспирант каф. Аетских инфекционных болезней, Национальный медицинский университет имени А. А. Богомольца, г. Киев, Украина.

Каминская Т. Н., А-р меА. наук, ассистент каф. Аетских инфекционных болезней, Национальный медицинский университет имени А. А. Богомольца, г. Киев, Украина. Гречуха Е. О., старший лаборант каф. Аетских инфекционных болезней, Национальный медицинский университет имени А. А. Богомольца, г. Киев, Украина.

\section{References}

[1] World Health Organization (WHO) (2018). Measles. Key facts. Retrieved from https://www.who.int/news-room/fact-sheets/detail/measles

[2] Santibanez, S., Hübschen, J., Ben Mamou, M., Muscat, M., Brown, K. \& Myers, R. et al. (2017). Molecular surveillance of measles and rubella in the WHO European Region: new challenges in the elimination phase. Clinical Microbiology And Infection, 23(8), 516-523. doi: 10.1016/j. cmi.2017.06.030

[3] World Health Organization (WHO) (2018). Ukraine restores immunization coverage in momentous effort to stop measles outbreak that has affected more than 12000 this year. Retrieved from http://www.euro. who.int/en/countries/ukraine/news/news/2018/05/ukraine-restores-immunization-coverage-in-momentous-effort-to-stop-measles-outbreakthat-has-affected-more-than-12-000-this-year

[4] Ludlow, M., McQuaid, S., Milner, D., de Swart, R., \& Duprex, W. (2015) Pathological consequences of systemic measles virus infection. The Journal Of Pathology, 235(2), 253-265. doi: 10.1002/path.4457

[5] de Vries, R., \& de Swart, R. (2014). Measles immune suppression: functional impairment or numbers game? Plos Pathogens, 10(12) e1004482. doi: 10.1371/journal.ppat.1004482

[6] Laksono, B., de Vries, R., McQuaid, S., Duprex, W., \& de Swart, R. (2016). Measles Virus Host Invasion and Pathogenesis. Viruses, 8(8), 210. doi: 10.3390/v8080210

[7] Laksono, B., Grosserichter-Wagener, C., de Vries, R., Langeveld, S. Brem, M., \& van Dongen, J. et al. (2018). In Vitro Measles Virus Infection of Human Lymphocyte Subsets Demonstrates High Susceptibility and Permissiveness of both Naive and Memory B Cells. Journal Of Virology, 92(8), e00131-18. doi: 10.1128/jvi.00131-18

[8] Grammens, T., Schirvel, C., Leenen, S., Shodu, N., Hutse, V., Mendes da Costa, E., \& Sabbe, M. (2017). Ongoing measles outbreak in Wallonia, Belgium, December 2016 to March 2017: characteristics and challenges. Eurosurveillance, 22(17). doi: 10.2807/1560-7917. es.2017.22.17.30524

[9] Ge, Y., Zhai, X., Zhu, Y., Wang, X., Xia, A., Li, Y., \& Zeng, M. (2017) Measles Outbreak in Pediatric Hematology and Oncology Patients in Shanghai, 2015. Chinese Medical Journal, 130(11), 1320-1326. doi: 10.4103/0366-6999.206358

[10] Griffin, D. (2014). Measles virus and the nervous system. Neurovirology, 577-590. doi: 10.1016/b978-0-444-53488-0.00027-4

[11] Fisher, D., Defres, S., \& Solomon, T. (2015). Measles-induced encephalitis. QJM, 108(3), 177-182. doi: 10.1093/qjmed/hcu113

[12] Wendorf, K., Winter, K., Zipprich, J., Schechter, R., Hacker, J., \& Preas, C. et al. (2017). Subacute Sclerosing Panencephalitis: The Devastating Measles Complication That Might Be More Common Than Previously Estimated. Clinical Infectious Diseases, 65(2), 226-232. doi: $10.1093 /$ cid/cix302

[13] Sati, S., Banga, S., \& Bhadouria, S. (2018). Fulminant Hepatic Failure in Measles in a 6-Month-Old Child. International Journal Of Clinical Pediatrics, 7(1-2), 17-18. doi: 10.14740/ijcp294w

[14] Caseris, M., Houhou, N., Longuet, P., Rioux, C., Lepeule, R., \& Choquet, C. et al. (2014). French 2010-2011 measles outbreak in adults: report from a Parisian teaching hospital. Clinical Microbiology And Infection, 20(4), 0242-0244. doi: 10.1111/1469-0691.12384

[15] Jackson, B., \& Black, R. (2017). Available studies fail to provide strong evidence of increased risk of diarrhea mortality due to measles in the period 4-26 weeks after measles rash onset. BMC Public Health 17(S4). doi: 10.1186/s12889-017-4745-2 